\title{
Effect of Cobalt Chloride on the Content of Lipid and Glycolytic Intermediates in Rabbit Liver and Heart
}

\author{
Kayoko Ohyama, Hiroyuki Morita, Takeshi Hasegawa and Shigeo Koike
}

Department of Hygine. School of Medicine Showa University, Tokyo

It has been reported that cardiomyopathy was the main cause of death in Quebec, Omaha and Minneapolis beer-drinkers, who drank a large quantity of beer containing cobalt chloride as a stabilizer of foam. Myocardial biopsies of Quebec beerdrinkers ${ }^{1)}$ revealed an increase of glycogen granules and accumulation of lipid droplets or vacuoles. Similar findings were noted in the cardiac muscles of rabbits injected with cobalt chloride ${ }^{2}$.

In a previous report $^{3)}$, hyperglycemia and triglyceridemia were described in cobalt-injected rabbits.

The present study was undertaken to see whether cobalt can bring about an increase in cardiac glycogen content or an accumulation of triglyceride in the hearts of rabbits. Hyperglycemia was investigated in conjunction with other glycolytic intermediates in the heart and liver. Triglyceridemia was pursued in relation to precursors of triglyceride, such as plasma FFA concentration, and to the liver triglyceride content, as well as ketogenesis in the liver.

\section{MATERIAL AND METHODS}

White male rabbits, weighing between 3 and $4 \mathrm{~kg}$, were divided into three comparable groups of ten each. The first group received free access to laboratory chow and water. It had been noted that after the first injection of cobalt chloride, rabbits ate little, and frequently nothing ate on the second or third day of injection. Moreover, it is well known that carbohydrate and lipid metabolisms is affected by starvation. Therefore, the second group was deprived of food for $72 \mathrm{hr}$. before sacrifice and served as a control for the third group. Group 3 was also starved for $72 \mathrm{hr}$. and $25 \mathrm{mg} / \mathrm{kg}$ of cobalt chloride was injected intramuscularly daily for three days. Blood was taken from the ear vein, and the animals were sacrificed by the injection of air into the ear vein. The heart and the liver were rapidly removed. The liver and the slices of the left ventricle wall were frozen in liquid nitrogen. For the assay of glycogen the sliced frozen ventricles were powdered with a pestle, and the powder was weighed. Thereafter glycogen was separated from the alkaline digest of the tissue by ethanol and determined after reaction with anthrone, as described by Seifter et $\mathrm{al}^{4)}$. For the assay of glucose, glucose-6-phosphate (G-6-P), fructose-6-phosphate (F-6-P), fructose-1, 6-diphosphate, the frozen liver and heart were powdered in a mortar, and the frozen powder was extracted with $3.3 \mathrm{~N}$ perchloric acid for glucose and with $6 \%$ perchloric acid for the phosphates. Glucose was assayed by the method of Bergmeyer, Bernt, Schmidt and Stork ${ }^{5}$. G-6-P and F-6-P were assayed by the method of Hohorst ${ }^{6}$. Fructose-1, 6-diphos phate was assayed by the method of Bücher and Hohorst ${ }^{7)}$. Liver and heart triglycerides were extracted by the method of Folch, Lees and Sloane ${ }^{8)}$ and determined by the same enzymatic method that was used for plasma triglyceride by Eggstein and Kuhlmann ${ }^{9}$. Plasma FFA was determined by the method of Laurell and Tibbling ${ }^{10)}$. Blood $\beta$-hydroxybutyrate and acetoacetate 
were determined by the enzymatic fluorimetric micromethod of Olsen ${ }^{11}$.

The comparison of the average concentration of triglyceride in heart, liver and plasma in the three groups of animals was performed by the transformation of each value into logarithms and tested according to analysis of variance, since the distribution of triglyceride concentration has been proved to be not normal and variations tended to increase markedly with concentration.

\section{RESULTS}

1. Effect of cobalt chloride and starvation on the content of glycolytic intermediates in the heart and liver.

The results of these experiments are given in Table 1 . In the hearts of starved rabbits,

Table 1. Effect of cobalt chloride on carbohydrate and lipid metabolism in heart, liver and blood of rabbits.

\begin{tabular}{|c|c|c|c|c|c|c|c|c|}
\hline & \multicolumn{6}{|c|}{ Heart } & \multicolumn{2}{|c|}{ Liver } \\
\hline & $\begin{array}{l}\text { Glycogen } \\
\mathrm{mg} / \mathrm{g}\end{array}$ & $\begin{array}{l}\text { Glucose } \\
\mu \text { moles } / \mathrm{g}\end{array}$ & $\begin{array}{l}\text { Glucose-6- } \\
\text { phosphate } \\
\mathrm{m} \mu \text { moles } / \mathrm{g}\end{array}$ & $\left|\begin{array}{l}\text { Fructose-6- } \\
\text { phosphate } \\
\mathrm{m} \mu \text { moles } / \mathrm{g}\end{array}\right|$ & $\mid \begin{array}{c}\text { Fructose- } \\
1,6 \text {-dipho- } \\
\text { sphate } \\
\mathrm{m} \mu \text { moles } / \mathrm{g}\end{array}$ & \begin{tabular}{|} 
Triglyce- \\
ride \\
$\mathrm{mg} / \mathrm{g}$
\end{tabular} & $\begin{array}{c}\text { Glucose } \\
\mu \text { moles } / \mathrm{g}\end{array}$ & $\begin{array}{l}\text { Glucose- } 6- \\
\text { phosphate } \\
\mathrm{m} \mu \text { moles } / \mathrm{g}\end{array}$ \\
\hline $\begin{array}{l}\text { Normally fed } \\
\text { rabbit }\end{array}$ & $\mid \begin{array}{c}(8) \\
3.03 \pm 0.64\end{array}$ & $\begin{array}{c}(9) \\
5.95 \pm 2.26\end{array}$ & $\begin{array}{c}(10) \\
287 \pm 138\end{array}$ & $\begin{array}{c}(10) \\
54 \pm 25\end{array}$ & $\begin{array}{c}(10) \\
57 \pm 22\end{array}$ & $\begin{array}{c}(10) \\
42.4 \pm 15.0\end{array}$ & $\begin{array}{c}(10) \\
17.3 \pm 6.5\end{array}$ & $\begin{array}{c}(10) \\
830 \pm 261\end{array}$ \\
\hline $\begin{array}{l}\text { Starved (72hr.) } \\
\text { rabbit }\end{array}$ & $\begin{array}{c}(8)^{* *} \\
4.15 \pm 0.80\end{array}$ & $\begin{array}{c}(9)^{* *} \\
3.62 \pm 0.93\end{array}$ & $\begin{array}{c}(10) \\
379 \pm 226\end{array}$ & $\begin{array}{c}(10) \\
67 \pm 46\end{array}$ & $\begin{array}{c}(10) \\
59 \pm 15\end{array}$ & $\mid \begin{array}{c}(10) \\
50.0 \pm 15.1\end{array}$ & $\begin{array}{c}(10) \\
14.3 \pm 5.4\end{array}$ & $\begin{array}{r}(10)^{* *} \\
347 \pm 98\end{array}$ \\
\hline \multirow[t]{3}{*}{$\begin{array}{l}\text { Cobalt-treated } \\
\text { Starved ( } 72 \mathrm{hr} .) \\
\text { rabbit }\end{array}$} & $\begin{array}{c}(8) \\
3.77 \pm 0.94\end{array}$ & $\begin{array}{c}(9)^{*} \\
4.44 \pm 1.55\end{array}$ & $\begin{array}{c}(10) \\
298 \pm 108\end{array}$ & $\begin{array}{c}(10) \\
55 \pm 21\end{array}$ & $\begin{array}{c}(10) \\
63 \pm 33\end{array}$ & $\begin{array}{c}(10) \\
59.4 \pm 22.7\end{array}$ & $\begin{array}{c}(10)_{+\dagger}^{*} \\
27.1 \pm 12.4\end{array}$ & $\begin{array}{r}(10)_{\dagger \dagger} \\
639 \pm 244\end{array}$ \\
\hline & \multicolumn{3}{|c|}{ Liver } & \multicolumn{2}{|c|}{ Plasma } & \multicolumn{3}{|c|}{ Blood } \\
\hline & \begin{tabular}{|l|} 
Fructose-6- \\
phosphate \\
$\mathrm{m} \mu$ moles $/ \mathrm{g}$
\end{tabular} & $\mid \begin{array}{c}\text { Fructose- } \\
1,6 \text {-dipho- } \\
\text { sphate } \\
\mathrm{m} \mu \text { moles } / \mathrm{g}\end{array}$ & $\begin{array}{c}\begin{array}{c}\text { Triglyce- } \\
\text { ride } \\
\mathrm{mg} / \mathrm{g}\end{array} \\
\end{array}$ & $\begin{array}{l}\text { Triglyce- } \\
\text { ride } \\
\mathrm{mg} / \mathrm{d} l\end{array}$ & $\begin{array}{c}\text { FFA } \\
\mu \mathrm{Eq} / \mathrm{L}\end{array}$ & $\begin{array}{c}\text { Glucose } \\
\mathrm{mg} / \mathrm{d} l\end{array}$ & $\begin{array}{c}\beta \text {-Hydroxy } \\
\text { butyrate } \\
\mu \text { moles } / \mathrm{L}\end{array}$ & $\begin{array}{l}\text { Acetoace- } \\
\text { tate } \\
\mu \text { moles } / \mathrm{L}\end{array}$ \\
\hline $\begin{array}{l}\text { Normally fed } \\
\text { rabbit }\end{array}$ & $\begin{array}{c}(10) \\
162 \pm 89\end{array}$ & $\begin{array}{c}(10) \\
31 \pm 17\end{array}$ & $\begin{array}{c}(10) \\
7.39 \pm 3.02\end{array}$ & $\begin{array}{c}(10) \\
50.5 \pm 17.6\end{array}$ & $\begin{array}{c}(10) \\
136 \pm 66\end{array}$ & $\begin{array}{c}(10) \\
142.0 \pm 41.8\end{array}$ & $\begin{array}{c}(9) \\
264 \pm 125\end{array}$ & $\begin{array}{c}(9) \\
14.7 \pm 19.5\end{array}$ \\
\hline $\begin{array}{l}\text { Starved (72hr.) } \\
\text { rabbit }\end{array}$ & $\begin{array}{c}(10)^{* *} \\
70 \pm 21\end{array}$ & $\begin{array}{c}(10) \\
30 \pm 16\end{array}$ & $\begin{array}{c}(10) \\
17.73 \pm \\
13.77\end{array}$ & $\begin{array}{c}(10)^{* *} \\
93.1 \pm 36.9\end{array}$ & $\begin{array}{r}(10)^{* *} \\
583 \pm 320\end{array}$ & $\begin{array}{c}(10) \\
130.7 \pm 16.8\end{array}$ & $\begin{array}{c}(10)^{*} \\
562 \pm 291\end{array}$ & $\begin{array}{c}(9) \\
53.2 \pm 20.6\end{array}$ \\
\hline $\begin{array}{l}\text { Cobalt treated } \\
\text { Starved ( } 72 \mathrm{hr} .) \\
\text { rabbit }\end{array}$ & $\begin{array}{r}(10)_{\dagger}^{\dagger} \\
131 \pm 54\end{array}$ & $\begin{array}{c}(10) \\
39 \pm 20\end{array}$ & $\begin{array}{c}(10)^{* *} \\
16.14 \pm \\
10.27\end{array}$ & $\begin{array}{c}(10)_{\mathrm{f}}^{* *} \\
354.9 \pm \\
159.0\end{array}$ & $\begin{array}{c}(10) \stackrel{*}{*} \\
375 \pm 149\end{array}$ & $\mid \begin{array}{c}(10)_{\dagger} \\
220.8 \pm \\
133.3\end{array}$ & $\begin{array}{c}(10)^{*} \\
469 \pm 259\end{array}$ & $\begin{array}{c}(8) \\
19.9 \pm 18.3\end{array}$ \\
\hline
\end{tabular}

* $\mathrm{P}<0.05$, ** $\mathrm{P}<0.01$ : for differences from normally fed rabbit

i $\mathrm{P}<0.05$, it $\mathrm{P}<0.01$ : for differences from starved (72hr.) rabbit

Numbers in parentheses indicate number of animals. Values are mean \pm SD.

the amounts of glycogen, G-6-P and F-6-P were increased, whereas the content of glucose was decreased. The administration of cobalt chloride to starved animals resulted in a slight but not significant fall in glycogen, G-6-P and F-6-P and a significant elevation of the glucose level.

In the livers of starved rabbits, a significant decrease in the content of G-6-P and F-6-P and a slight fall in the glucose content were observed in comparison with normally fed animals. The administration of cobalt chloride to starved animals produced significant rises in the glucose, G-6-P and F-6-P content, but did not significantly alter the fructose-1, 6diphosphate content; these alterations were found to be associated with high blood glucose 
levels.

2. Effect of cobalt chloride and starvation on lipid metabolism in the blood, heart and liver.

The blood triglyceride level was greatly influenced by cobalt chloride treatment. In the treated group, it was four times that in the starved groups and seven times that in the normally fed group. The increase of triglyceride in the heart was highest in the cobalt treated rabbits, and intermediate in the starved group, but the difference among the three groups was not significant. Despite very high blood triglyceride levels in the cobalt-treated rabbits, the hepatic content of triglyceride was almost the same in cobalt-treated and starved rabbits. Starvation caused a marked elevation of plasma FFA as well as of blood $\beta$-hydroxybutyrate, and the administration of cobalt chloride to starved rabbits brought about a significant fall in the level of plasma FFA, but did not significantly alter the blood ketone body levels.

\section{Discussion}

Histochemical studies of the cardiac muscles of Quebec beer-drinkers revealed marked and diffuse accumulation of sudanophilic material appearing as fine droplets in all parts of the sarcoplasm ${ }^{1)}$. In the myocardium of cobalt-treated rabbits, a striking increase of lipid was detected by histological stains for neutral lipid with sudan IV and oil red $0^{2}$. The present experiment showed that the triglyceride content of hearts in cobalt-treated starved rabbits was higher than in normally fed or starved animals, but the differences were not statistically significant. In our study, $25 \mathrm{mg} / \mathrm{kg}$ of cobalt chloride was injected daily for three days, whereas in the study of Hall et al. ${ }^{2}$, rabbits were injected in doses of 15 to 25 $\mathrm{mg} / \mathrm{kg} / 24 \mathrm{hrs}$. for 9 to 13 days until definite clinical signs of toxicity appeared. The difference in duration of administration or in total amount of injected between Hall's study and ours might account for the fact that no significant increase of triglyceride could be observed even though a remarkable increase of lipid was confirmed histologically.

In contrast to light microscopy, electron microscopy of biopsy specimens obtained from the hearts of the Quebec beer-drinkers revealed abundant glycogen below the sarcolemma ${ }^{12)}$ and intracellule ${ }^{1)}$. Numerous glycogen granules were also observed by electron microscopy in the myocardium of cobalt treated rabbits ${ }^{2}$. The present experiment showed that the glycogen content was higher in the hearts of rabbits treated with cobalt chloride than in those of normally fed rabbits but lower than in those of starved animals. These differences are not significant statistically, but suggest that cobalt tends to lower the elevated glycogen content of the heart induced by starvation. Evans ${ }^{13)}$ demonstrated that in fasted rats the glycogen content in the heart was raised, and Adrouny and Russel ${ }^{14)}$ confirmed this observation. Jedeikin ${ }^{15)}$ noted that elevated cardiac glycogen concentrations in starved rats were due to diminished glycogen synthesis and utilization.

- In the hearts of starved ( $72 \mathrm{hrs}$.) rabbits, a significant decrease in the content of glucose was observed accompanied by a fall in the blood glucose level and an elevation of plasma FFA, blood $\beta$-hydroxybutyrate and acetoacetate. Therefore, elevation of cardiac glycogen may be regarded as a reflection of decreased glycolysis and the sparing of glycogen, since increased levels of FFA or ketone bodies may be utilized as energy sources to spare glycogen. A slight fall in the content of glycogen following cobalt treatment of starved rabbits can account for the hyperglycemia as well as the higher content of glucose in the heart, since glucose is the only effective exogenous glycogen precursor, because of the absence of the enzyme fructose-1, 6-diphosphatase in the heart ${ }^{16,17)}$.

G-6-P and F-6-P were increased in starved rabbits hearts, but in cobalt-treated rabbits they remained at normal levels. Newsholme and Randle ${ }^{18)}$ found that the concentrations of G-6-P and F-6-P were increased and that of fructose-1, 6-diphosphate was decreased in hearts, 
which had been extirpated from rats starved for $30 \mathrm{hr}$. and then perfused for $15 \mathrm{~min}$. through the coronary vessels. The present experiments showed that the injection of cobalt chloride in starved rabbits caused the hexose monophosphate content to return to normal. Hexose monophosphate must be utilized by entering pathways of either glycolysis or glycogen synthesis since the heart lacks glucose-6-phosphatase. When glycolysis is decreased by starvation, either an increase in the content of G-6-P and F-6-P or the accumulation of glycogen may occur. The slight rise in the heart glucose level in the cobalt-treated animals might act to prevent the rise of hexose monophosphate or glycogen.

In the livers of starved animals, glucokinase has been reported ${ }^{19)}$ to fall and glucose-6phosphatase to increase. Therefore, glucose production is facilitated without a marked fall in the concentration of blood glucose which follows the fall in the content of G-6-P20) and F-6- $\mathrm{P}^{21)}$ in the liver. As shown in the previous and also in the present experiment, hyperglycemia was a prominent feature in cobalt-treated rabbits. The mechanism involved in the cause of this hyperglycemia is not clear. It has been reported ${ }^{22,23,24)}$ that cobalt chloride produced morphologic evidence of alpha cell damage when administered to rabbits. Lochner ${ }^{25)}$ et al. reported that no evidence of significant depletion of pancreatic glucagon was observed in rats during the three days after treatment with cobalt chloride, nor did glucagon levels decline significantly at any time. Fodden and $\operatorname{Read}^{26)}$ reported a rise in extractable glucagon in rabbits after cobalt treatment. The reduction of insulin secretion and the concomitant increase of glucagon secretion may cause elevation of blood glucose. Whatever the cause may be, the resulting hyperglycemia may be responsible for the high content of glucose in the liver, since glucose can freely enter the liver cells ${ }^{19)}$. The present study reveals that in starved rabbits, the administration of cobalt raises hepatic glucose significantly. Cahill et al. ${ }^{19)}$ reported that at blood glucose concentrations of $200 \mathrm{mg}$ per cent, glucokinase phosphorylates more glucose molecules than are cleaved by glucose-6-phosphatase and thus the concentration of glucose-6-phosphate increases and glycogen is deposited in the liver. In the present experiment, the administration of cobalt caused the average concentration of blood glucose to rise over $200 \mathrm{mg}$ per cent, so hepatic G-6-P and F-6-P increased even in the state of starvation.

Cobalt chloride has been known to produce lipemia in both man and animals ${ }^{3}$, but the mechanism responsible for this lipemia has yet to be shown. The study showed that the plasma triglyceride concentration of cobalt-treated rabbits was more than seven times the nomal level and three times the level in starved rabbits. The triglyceride content in the livers of cobalt-treated rabbits was also increased but no significant difference was observed in comparison with that in starved animals. Havel ${ }^{31)}$ demonstrated that the hepatic triglyceride fatty acid content of starved rabbits was higher than in re-fed rabbits. A previous experiment showed that the triglyceride content of the liver of cobalt treated rabbits was higher than that of starved rabbits. The discrpancy between the significantly higher content of liver triglyceride seen previously and the similar content seen in this experiment is yet to be elucidated.

It is generally believed ${ }^{32)}$ that the increased rate of hepatic ketogenesis during fasting is secondary to an increase in FFA catabolism resulting from the high rate of FFA flux to the liver from adipose tissue. In the present study, as in the previously reported ${ }^{3)}$, the plasma FFA level was high in both starved and cobalt-treated rabbits, but higher in the former. Both groups of animals were fasted similarly, but cobalt treatment probably suppressed the release of FFA from adipose tissue. Eaton $^{33)}$ advanced the hypothesis that the cobalt ion could potentiate insulin action, stimulate insulin action, or act in some combination of the two alternatives. If this is so, the suppression of the plasma FFA level in cobalt-treated 
animals may be explained by the action of cobalt, similar to that of insulin, in depressing the cellular level of cyclic AMP which follows the reduction of lipolysis.

An increased delivery of FFA to the liver leads either to esterification, i. e. triglyceride formation, or to oxidation. The present experiment shows that triglyceride formation is similar in starved and cobalt-treated rabbits. Only those fatty acids not utilized for esterification become available for oxidation, but the cobalt ion reacts with the SH group of dihydrolipoic acid ${ }^{35)}$ and prevents oxidative decarboxylation of alpha-ketoglutarate to succinyl CoA in the citric acid cycle ${ }^{36)}$. Thus those fatty acids not utilized for esterification or oxidation proceed to ketogenesis and may bring about rather high concentrations of $\beta$-hydroxybutyrate comparable to the plasma FFA level.

\section{SUMMARY}

The effects of cobalt chloride on various parameters of lipid and carbohydrate metabolism were examined in rabbit heart and liver. Hyperglycemia induced by cobalt chloride acted to elevate the glucose content of the heart, and also elevated the glucose, G-6-P and F-6-P content of the liver in starved rabbits.

Marked elevation of plasma triglyceride levels in cobalt treated rabbits was accompanied by the accumulation of triglyceride in the liver; the triglyceride content of the heart was increased but not significantly, so. Cobalt acted to reduce the elevated concentration of plasma FFA induced by starvation. Plasma FFA might be utilized similarly in both cobalt-treated and starved rabbits to elevate the triglyceride content of the liver and the blood $\beta$-hydroxybutyrate concentration.

\section{ACKNOWLEGEMENT}

The authors wish to express their gratitude to Miss Yōko Onuma, for her technical assistance.

\section{REFERENCES}

1) Bonenfant, J-L., Miller, G. and Roy, P. E.: Quebec beer-drinkers' cardiomyopathy. Pathologic studies, Canad. Med. Assc. J. 97, 910-916 (1967).

2) Hall, J. L. and Smith, E. B.: Cobalt heart disease, an electron microscopic and histochemical study in the rabbit, Arch. Path. 86, 403-412 (1968).

3) Asano, S., Ohyama, K. and Koike, S.: Accumulation of triglyceride in rabbit liver induced by injection of cobalt chloride, Jap. J. Hyg., 27, 105 (1972).

4) Seifter, S., Dayton, S., Novic, B. and Muntwyler, E.: The determination of glycogen with the anthrone reagent, Arch. Biochem. Biophys., 25, 191-200 (1951).

5) Bergmeyer, H. U., Bernt, E. Schmidt, F. und Stork, H.: Bestimmung der Glucose mit Hexokinase und Glucoe-6-phosphat-Dehydrogenase, in Methoden der enzymatischen Analyse, (Herausgeben von H. U. Bergmeyer) S. 1163, Verlag Chemie, Berlin (1970).

6) Hohorst, H-J.: D-Glucose-6-phosphat und D-Fructose-6-phosphat, in Methoden der enzymatischen Analyse, (Herausgeben von H. U. Bergmeyer) S. 1200. Verlag Chemie, Berlin (1970).

7) Bücher, J. und Hohorst, H. J.: D-Fructose-1, 6-diphosphat, Dihydroxyaceton-phosphat und D-Glycerinaldehyd-3-phosphat, in Methoden der enzymatischen Analyse, (Herausgeben von H. U. Bergmeyer) S. 1282, Verlag Chemie, Berlin (1970)

8) Folch, J., Lees, M. and Sloane, G. H.: A simple method for the isolation and purification of total lipids from animal tissues, J. Biol. Chem., 226, 479-506 (1957).

9) Eggstein, M. und Kuhlmann, E: Triglyceride und Glycerin, in Methoden der enzymatischen Analyse 
(Herausgeben von H. U. Bergmeyer) S. 1765, Verlag Chemie, Berlin (1970).

10) Laurell, S. and Tibbling, G.: Colorimetric microdetermination of free fatty acids in plasma, Clin. Chim. Acta, 16, 57-62 (1967).

11) Olsen, C.: An enzymatic fluorimetric micromethod for the determination of acetoacetate, $\beta$-hydroxybutyrate, pyruvate and lactate, Clin. Chim. Acta, 33, 293-300 (1971)

12) Alexander, C. S.: Cobalt cardiomyopathy, A clinical and pathological study of twenty-eight cases, Am. J. Med., 53, 395-417 (1972).

13) Evans, G.: J. Physiol. 82, 468 (1934).

14) Adrouny, G. A. and Russhel, J. A.: Effect of growth hormone and nutritional status on cardiac glycogen in the rat, Endocrinology, 59, 241-251 (1956).

15) Jedeikin, L. A.: Cardiac glycogen metabolism in vivo in fed and starved rats, Biochem. J., 99, 6p (1966).

16) Krebs, H. A. and Woodford, M.: Fructose-1, 6-diphosphatase in striated muscle, Biochem. J., 94, 436-445 (1965)

17) Opie, L. H. and Newsholme, E. A.: The activities of fructose-1, 6-diphosphatase, phosphofructokinase and phosphoenolpyruvate carboxykinase in white muscle and red muscle, Biochem. J., 103, 391-399 (1967)

18) Newsholme, E. A. and Randle, P. J.: Regulation of glucose uptake by muscle, 5. Effects of anoxia, insulin, adrenaline and prolonged starving on concentrations of hexose phosphate in isolated rat diaphragm and perfused isolated rat heart, Biochem. J., 80, 655-662 (1961)

19) Cahill, G. F. Jr., Ashmore, J., Renold, A. E. and Hasting, A. B.: Blood glucose and liver, Am. J. Med., 26, 264-282 (1959)

20) Steiner, D. F. and Williams, R. H.: Some observations concerning hepatic glucose-5-phosphate content in normal and diabetic rats, .T. Biol. Chem., 234, 1342-1346 (1959)

21) Start, C. and Newsholme, E. A.: The effects of starvation and alloxan-diabetes on the contents of citrate and other metabolic intermediates in rat liver, Biochem. J., 107, 411-415 (1968).

22) Goldner, M. G., Volk, B. W. and Lazarus, S. S.: The effect of cobaltous chloride on the blood sugar and alpha cells in the pancreatic islets of the rabbit, Metabolism, 1, 544-548 (1952)

23) Volk, B. W., Lazarus, S. S. and Goldner, M. G.: Alpha cell damage and blood sugar changes in rabbits after administration of cobalt, Proc. Soc. Exp. Biol. Med., 82, 406-411. (1953)

24) Fodden, J. H.: Experiments with chemicals noxious to the pancreatic alpha cells, Am. J. Clin. Path., 23, 1002-1011 (1953)

25) Lochner, J. V., Eisentraut, A. M. and Unger, R.H.: The effect of $\mathrm{CoCl}_{2}$ on glucagon levels in plasma and pancreas of the rat, Metabolism, 13, 868-874 (1964)

26) Fodden, J. H. and Read, W. H.: The activity of extracted pancreatic hyperglycemic-glycogenolytic factor after cobaltous chloride and synthalin A, Endocrinology, 54, 303-310 (1944)

27) Asano, S., Komaya, M. and Koike, S.: Hypertriglyceridemia and change of serum LDH activity in experimental animals injected with cobalt compound, Jap. J. Hyg., 25, 453-458 (1970)

28) Caplan, R. M. and Block, W. D.: Experimental production of hyperlipemia in rabbits by cobaltous chloride, J. Invest. Dermatol., 40, 199-203 (1963)

29) Robey, J. S., Veazey, P. M. and Crawford, J. D.: Cobalt-induced myxedema, Report of a case, New Engl. J. Med., 255, 955-957 (1956)

30) Caplan, R. and Curtis, A.: Xanthoma of the skin, J. Am. Med. Assoc., 176, 859-863 (1961)

31) Havel, R. J., Felts, J. M. and Van Duyne, C. M.: Formation and fate of endogenous triglycerides in blood plasma of rabbits, J. Lip. Res., 3, 297-308 (1962)

32) Masora, E. J.: Physiological chemistry of lipids in mammales, P. 218, Saunders Comp. Philadelphia (1968)

33) Eaton, R. P.: Cobalt chloride-induced hyperlipemia in the rat: effects on intermediary metabolism, Am. J. Physiol., 222 1550-1557 (1972)

34) Mc Garry, J. D. and Foster, D. W.: Regulation of ketogenenesis and clinical aspects of the ketotic state, Metabolism, 21, 471-489 (1972)

35) Webb, M.: The biological action of cobalt and other metals, III. Chelation of cations by dihydroxylipoic acid, Biochim. Biophys. Acta, 65, 47-65 (1962)

36) Alexander, C. S.: Cobalt and the heart, Annals Int. Med., 70, 411-413 (1969) 


\title{
塩化コバルトによる家鬼の肝および心の脂質ならびに 糖質代謝におよぼす影響について
}

\author{
昭和大学医学部衛生学教室 \\ 大山佳代子・森 田博 行 \\ 長谷川武志・小池重夫
}

体重 $1 \mathrm{~kg}$ 当り $25 \mathrm{mg}$ の塩化コバルトを空腹状態のオス家鬼に毎日 1 回 3 日間注射して肝, 心の脂質ならびに糖 質代謝の中間生成物に及ぼす影響を観察した。

塩化コバルト注射にって血糖は影著に上昇し，心では空腹によって低下したブドウ糖は増加した。肝では塩 化コバルトによる血糖上昇に伴ってブドウ糖は顕著に上昇し, 空腹によって減少した $\mathrm{G}-6-\mathrm{P}, \mathrm{F}-6-\mathrm{P}$ の含有量 は増加した。

塩化コバルトによって血漿のトリグリセライド (TG) は空腹群に比べて約 4 倍増加したが心の TGは増加の傾 向を示し, 肝の TG む正常摂食群に比べて増加したが空腹群に比へて有意差はなかった。塭化コバルト注射によ って，空腹状態で上昇した血漿 FFA は減少したが正常摂食群に比べると増加していた。

上昇した血漿 FFA は肝でエステル化されて TG の合成に消費されたが残りは Ketone 体合成に使われ，コバ ルト注射群と空腹群との血中の $\beta$-Hydroxybutyrate 量の上昇は同じ程度であった。 